Meta

Journal des tradlucteurs

Translators' Journal

\title{
Report on FIT North American Regional Congress, Mexico-City, February 26-28, 1986
}

\section{Nancy Schweda-Nicholson}

Volume 31, numéro 4, décembre 1986

URI : https://id.erudit.org/iderudit/004075ar

DOI : https://doi.org/10.7202/004075ar

Aller au sommaire du numéro

Éditeur(s)

Les Presses de l'Université de Montréal

ISSN

0026-0452 (imprimé)

1492-1421 (numérique)

Découvrir la revue

\section{Citer cette note}

Schweda-Nicholson, N. (1986). Report on FIT North American Regional

Congress, Mexico-City, February 26-28, 1986. Meta, 31(4), 454-455.

https://doi.org/10.7202/004075ar d'utilisation que vous pouvez consulter en ligne. 


\section{BLOC-NOTES}

\section{REPORT ON FIT NORTH AMERICAN REGIONAL CONGRESS MEXICO CITY, FEBRUARY 26-28, 1986}

The First North American Translators Congress took place in Mexico City. February 26-28, 1986. The sponsor organizations were the Asociacio de Traductores Profesionales (ATP), the American Translators Association (ATA), the Canadian Translators and Interpreters Council (CTIC), and the Regional Centers Committee of the International Translators Federation (FIT). The Congress was held in conjunction with the Third Symposium on Problems in Literary Translation sponsored by the Instituto Nacional de Bellas Artes (INBA), the Fondo de Cultural Economica (FCE), and the Instituto Superior de Intérpretes y Traductores (ISIT). The landmark event brought together literary and scientifictechnical translators, interpreters, terminologists, linguists, and translator/interpreter trainers from Canada, the United States, and Mexico. Moreover, many Mexican students from area schools attended the meetings.

Unlike many rather sterile conference settings, the site of the Congress was the $\mathrm{Museo} \mathrm{Na}$ cional de Arte (MUNAL) located in downtown Mexico City. All of the sessions were held in a large room at the Museum whose ceiling was an artistic masterpiece. In addition, the conference room was beautifully decorated with paintings. Such magnificent surroundings lent a special air to the Congress.

Thirty-six invited speakers $(12$ each from Canada, Mexico, and the United States) comprised the program. Gregory Rabasa, a noted translator of Latin American literature into English delivered the keynote address on Wednesday morning. The titles of the general sessions were: (1) "Legal and Social Status of the Translator and Interpreter"; (2) "Technical and Scientific Translation"; (3) "Sciences of Language Applied to Translation and Interpretation"; (4) "Literary Translation"; (5) "Education, Training, and Accreditation of Translators and Interpreters"; and (6) "Multilingualism and Translation".

Panel (1) speakers were Alejandro Zenker, Director General of ISIT and the President of ATP;
Patricia Newman, President of the American Translators Association; and Jean-Francois Joly, President of the CTIC and the Société des traducteurs $d u$ Québec (STQ). The session was of interest to all conference participants because the panelists spoke about the status of translators and interpreters in their respective countries. This panel set the stage for much additional discussion of how to improve the overall status of translators and interpreters throughout the world.

Other recurring subjects of discussion were (1) the importance of quality scientific and technical translation and interpretation in an increasingly complex world; (2) the use of computer software to facilitate the translation process; (3) the role of linguistics in translation and interpretation; (4) the scope and usefulness of terminology data banks; (5) identification of the best methods to screen and train translators and interpreters; and (6) the challenges and the role of literary translation.

All of the panels were followed by lively discussion sessions; the audience members (almost 200 strong) played an active role by addressing both interesting and provocative questions to the panelists. It was often the case that not all of the question could be answered in the time allotted, so the audience was encouraged to consult with individual speakers after the meetings.

Throughout the conference, simultaneous interpretation was provided in English, Spanish, and French under the able direction of Georganne Weller, Co-Director of Interpretation Training at ISIT.

Between sessions, participants browsed through book exhibits and learned about computerassisted translation via hands-on demonstrations.

The high quality presentations were not the only highlight of the Congress. Participants also had the opportunity to experience the cultural richness of Mexico. Our sponsors graciously organized an evening at the Ballet Folklorico de Mexico, a Mexican buffet complemented by a mariachi orchestra, and a visit to the Templo Mayor. As well, welcoming and closing cocktail receptions afforded the participants the opportunity to discuss issues raised at the Congress in an informal setting. 
Anna Lilova, the President of FIT, joined the conference to formally establish the FIT North American Regional Center. The Center will hold a congress every three years in one of the three member countries on a rotating basis. The next congress will be held in Boston in 1989, and the host organization will be the American Translators Association.

All in all, the First North American Translators Congress can be viewed as an unqualified success. It brought together language specialists from numerous related disciplines and engendered lively discussion on many pertinent topics. I believe that all of the participants are looking forward to the Next Congress in 1989.

NANCY SCHWEDA-NICHOLSON

University of Delaware, Delaware, USA 